\title{
Cardiac Resynchronization Therapy in Heart Failure Management
}

\author{
Hilman Zulkifli Amin, Siska Suridanda Danny
}

'Faculty of Medicine, Universitas Indonesia

2Department of Cardiology and Vascular Medicine, Faculty of

Medicine, Universitas Indonesia
Heart failure $(\mathrm{HF})$ is a worldwide health problem with high prevalence rate. The prevalence is over 23 million worldwide. It is a chronic disease characterized by the inability of the heart to pump an adequate amount of blood to achieve the demand of the different organ systems and/or doing so at increased filling pressures. Despite many recent advances in medication, the rate of people with HF is rising. This health challenges need to be answered properly. One of the new important treatment for HF is cardiac resynchronization therapy (CRT). Many patients with HF also have an abnormality of the heart's electrical system resulting in asynchronous contraction pattern of heart muscle.

The ultimate goal of CRT is to restore synchrony of the heart rhythm in HF patients. CRT implantation in heart failure patients with proper indications like wide QRS complexes, low left ventricular ejection fraction (LVEF), and left bundle branch block (LBBB) has been proved to reduce morbidity, mortality, and also improve symptoms and quality of life (QoL).

(J Kardiol Indones. 2015;36:227-36)

Keywords: heart failure, cardiac resynchronization therapy 
Jurnal

Kardiologi Indonesia

J Kardiol Indones. 2015;36:227-36

ISSN $0126 / 3773$

Tinjauan Pustaka

\title{
Terapi Resinkronisasi Jantung pada Penanganan Gagal Jantung
}

\author{
Hilman Zulkifli Amin, Siska Suridanda Danny
}

\begin{abstract}
Gagal jantung (GJ) merupakan masalah kesehatan utama dunia dengan tingkat prevalensi yang tinggi. Di seluruh dunia, prevalensi GJ mencapai 23 juta orang. GJ merupakan penyakit kronik dengan karakteristik berupa ketidakmampuan jantung dalam memompa darah untuk memenuhi kebutuhan sistem organ dan atau diikuti dengan terjadinya peningkatan tekanan isi sekuncup. Meskipun telah banyak kemajuan dalam pengobatan GJ, jumlah penderita GJ terus meningkat. Tantangan dalam dunia kesehatan ini perlu segera dipenuhi. Salah satu terapi baru dan penting dalam penanganan GJ ialah terapi resinkronisasi jantung (TRJ). Terdapat banyak pasien GJ juga mengalami abnormalitas sistem konduksi jantung yang menyebabkan terjadinya ketidaksinkronan pola kontraksi otot jantung.

Tujuan utama dari TRJ ialah mengembalikan sinkronisasi ritme jantung pada pasien GJ. Pemasangan TRJ pada pasien GJ dengan indikasi yang tepat dan sesuai seperti kompleks QRS yang lebar, ejeksi fraksi ventrikel kiri yang rendah, dan blok berkas cabang kiri telah terbukti dapat menurunkan angka morbiditas, mortalitas, dan juga meningkatkan kualitas hidup serta memperbaiki gejala.
\end{abstract}

(J Kardiol Indones. 2015;36:227-36)

Kata kunci: gagal jantung, terapi resinkronisasi jantung

$\mathrm{H}$ eart failure (HF) is a chronic disease characterized by the inability of the heart to pump an adequate amount of blood to achieve the demand of the different organ systems and/or doing so at increased filling pressures. ${ }^{1}$ HF caused by the weakening of the heart muscle. It is most commonly caused by irreversible damage from coronary artery disease, but may also be result of viral infections, genetic factors, or toxins. ${ }^{2}$

\section{Alamat Korespondensi}

dr. Hilman Zulkifli Amin, Faculty of Medicine, Universitas Indonesia, Jl. Salemba Raya No. 6, Jakarta, Indonesia. E-mail: hilman_amin@ yahoo.co.id
HF is a worldwide health problem with high prevalence rate. The prevalence is over 23 million worldwide. ${ }^{3}$ This disease carries substantial risk of morbidity and mortality. Over 2.4 million patients are hospitalized and nearly 300,000 deaths annually are directly attributable to HF. There is a dramatic increase in the prevalence of HF. The growing prevalence of HF might reflect increasing incidence, an aging population, improvements in the treatment of acute cardiovascular disease and HF, or combination of these factors. Since then, medications are the mainstay therapy for patients with HF.

Medications help rid the body extra fluid, strengthen the heart's contraction, and ease the heart's workload by relaxing the blood vessels and reducing 
the resistance to pumping blood. ${ }^{3}$ Despite many recent advances in medication, the rate of people with HF is rising. This health challenges need to be answered properly. One of the new important treatment for $\mathrm{HF}$ is cardiac resynchronization therapy (CRT). Many patients with HF also have an abnormality of the heart's electrical system resulting in asynchronous contraction pattern of heart muscle.

\section{Heart Electrical System Conduction In HF}

The normal heart rhythm is originated by an electrical signal from a region of the right atrium (RA) known as the sinoatrial or SA node. After that, the electrical signal run through both atria and make them pump blood into the ventricles. ${ }^{3}$ The atrioventricular node or AV node, then is reached by an electrical signal. The signal then spreads through specialized routes called the left and right bundle branch branches. Finally, the bundle branches stimulate both ventricles to contract synchronously. This electrical system conduction is important for optimal blood pumping to all over body.

The most common abnormality conduction in HF patient is left bundle branch block (LBBB). ${ }^{3}$ Because of this block, the right ventricle made an earlier contraction than the left ventricle, instead of simultaneously. The result is an asynchronous contraction of the ventricles. Eventually, cardiac pump will lose its efficiency. Almost $40 \%$ of HF patients have an asynchronous ventricular contraction caused by electrical delay, most often LBBB. The appearance of this electrical delay on an electrocardiogram (ECG) is widening of the QRS complex.

\section{Cardiac Resynchronization Therapy (CRT)}

The ultimate goal of CRT is to restore synchrony of the heart rhythm in HF patients. It is a unique type of cardiac pacemaker. ${ }^{5}$ Pacemakers usually being used to prevent symptoms associated with symptomatic slow heart rates. The patient's heart rate is continuously monitored by the pacemaker. The heart rate is stimulated by the pacemaker by delivering a tiny electrical charge when necessary. ${ }^{3}$ Common pacemakers have 2 leads, one in the right atrium and one in the right ventricle, in order to keep the normal pump function relationship between bottom and top of the heart. These leads are connected to a pulse generator placed under the skin in the upper chest.

CRT is a specialized type of pacemakers, that have a third lead which is positioned in a vein on the outer surface of the left ventricle, in addition to the 2 leads used by common pacemakers. 3,5 This allows a synchronous pumping action of left and right ventricle.

There are two types of CRT, a CRT pacemaker and a combination CRT pacemaker with defibrillation therapy (CRT-D). ${ }^{5}$ Both help to coordinate the heart pumping action and improve blood flow. In CRT-D, it also has the ability to detect and treat malignant heart rhythms, which some individuals with a damaged heart muscle may be at risk for developing. The decision of which device to use depends on the physician.

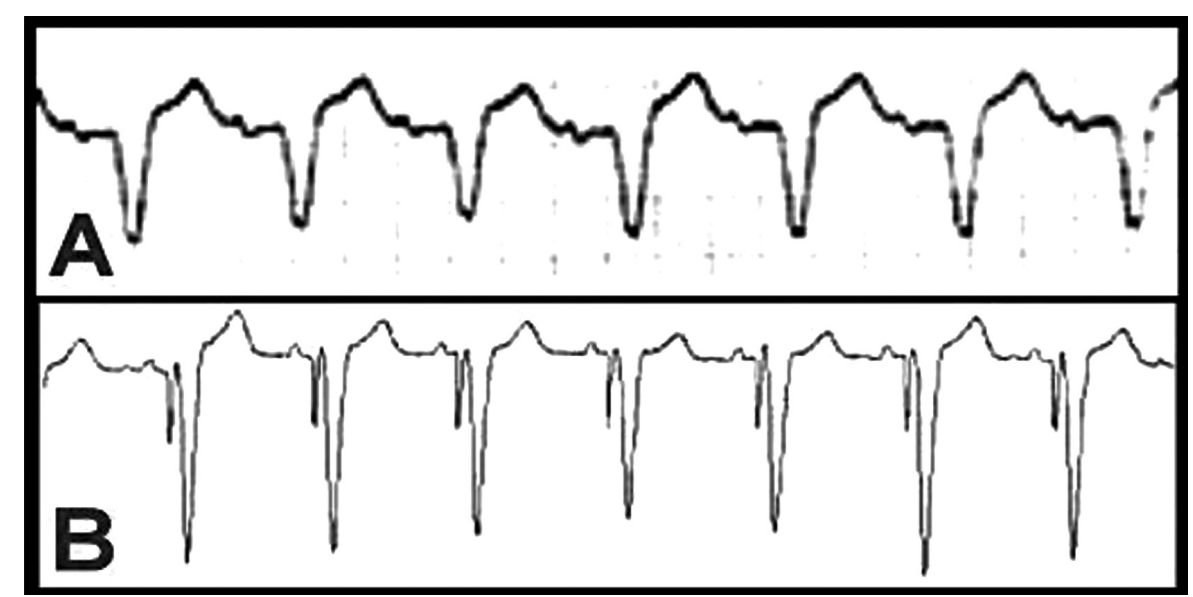

Figure 1. LBBB and Improvement of Conduction System by CRT ${ }^{4}$ 


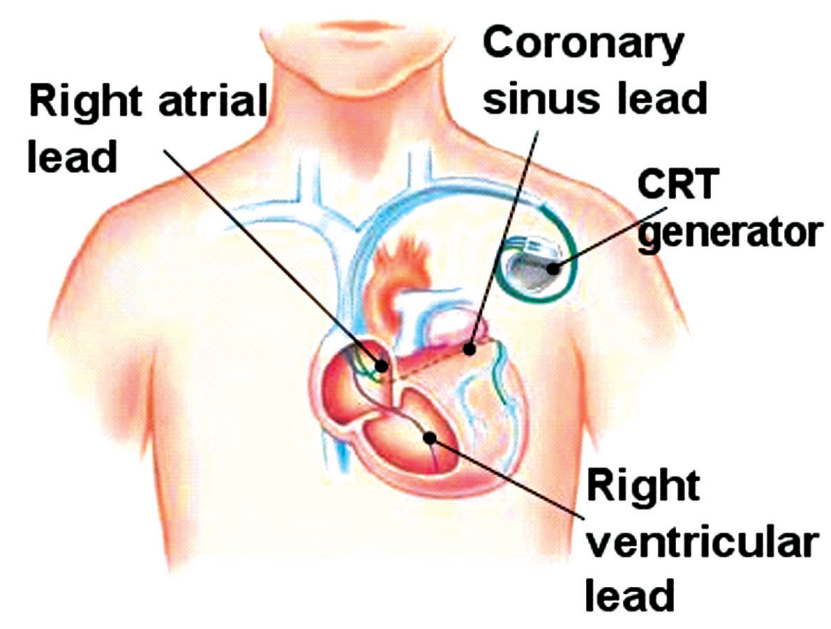

Figure 2. CRT Lead Placement ${ }^{4}$

\section{Indications and Benefits of CRT in Heart Failure Management}

Many conclusive evidences of CRT benefits in HF from several randomized clinical trials (RCTs). ${ }^{6}$ The inclusion criteria used in the most RCTs was, New York Heart Association (NYHA) functional class III-IV in sinus rhythm (SR), low left ventricular ejection fraction $(\mathrm{LVEF})<35 \%$, and duration of QRS interval $\geq 120$ ms. The Cardiac Resynchronization in Heart Failure (CARE-HF) trials with 813 patients evaluated all-cause mortality, hospitalization, NYHA functional class, and quality of life (QoL). ${ }^{6,7}$ This study was doubleblinded and randomized trial. The result was CRT proved to reduce all-cause mortality, hospitalization, improved NYHA functional class, and QoL. Other study showing similar result was Comparison of Medical Therapy, Pacing, and Defibrillation in Heart Failure (COMPANION) trial. This study even has larger subjects which was 1520 patients. ${ }^{6,8}$ The result was also the same that CRT could reduced all-cause mortality or hospitalization. Other studies like Multisite Stimulation in Cardiomyopathy (MUSTIC), Pacing Therapies in Congestive Heart Failure (PATHCHF), and Multicenter InSync Randomized Clinical Evaluation (MIRACLE) trials also showed superiority of CRT in HF paients. ${ }^{6,9-11}$ These studies proved that CRT could improved QoL, NYHA functional class, 6-minutes walk distance (6MWD), LVEF, and peak $\mathrm{VO}_{2}$.
However, in accordance to the low number of subjects enrolled in RCTs, the evidence in HF patients with NYHA functional class IV was limited (from 7 to $15 \%) .{ }^{6}$ Ambulatory HF patients functional class IV showed a significant reduction in the combined primary endpoint of time to all-cause mortality and hospitalization as shown in a sub-study of COMPANION trial. ${ }^{6,8}$ The summary of the RCTs of CRT benefit in HF patients with NYHA functional class III-IV, sinus rhythm, poor left ventricular ejection fraction (LVEF), and prolonged QRS interval ( $\geq 120$ $\mathrm{ms}$ ) will be shown on the table below.

Other topic related to the CRT benefit in HF patients was the impact of QRS duration on the efficacy of CRT. Subgroup analysis, in a recent meta-analysis from COMPANION and CARE-HF trials, evaluating the impact of QRS duration on the efficacy of CRT, has shown that, in NYHA functional class III-IV HF patients, CRT significantly reduced all-cause mortality or hospitalization in patients with QRS duration $\geq 150$ ms. ${ }^{6-8}$ The effect and benefit of CRT declined with shorter QRS duration. These studies also supported by Multicenter Automatic Defibrillator Implantation Trial with Cardiac Resynchronization Therapy (MADIT-CRT) trial. $^{6,12}$ It showed that patients with a QRS duration $\geq 150 \mathrm{~ms}$, has a most benefit effect from CRT and suggested that it might not effective in patients with QRS $<150$ ms. In addition, most patients in the RCTs had LBBB morphology, which was associated, with a more pronounced benefit, compared with non-LBBB patients. It was shown in the MADIT-CRT, ResynchronizationDefibrillation for Ambulatory Heart Failure (RAFT), and Resynchronization Reverses Remodelling in Systolic Left Ventricular Dysfunction (REVERSE) trials, and a meta-analysis of COMPANION, CARE-HF, MADITCRT, and RAFT.6,12-14 Patients with complete LBBB, showed a greater benefit on the composite of morbidity and mortality from CRT, compared with patients with non-specific IVCD or RBBB. ${ }^{6}$ However, patients with LBBB had longer QRS duration, and therefore analyses by morphology may be confounded by QRS duration. On the other hand, the MADIT-CRT trial showed that non-LBBB patients did not derive clinical benefit from CRT (statistically not significant $24 \%$ increased risk). ${ }^{6,12}$ Other trials also showed consistent results that indicated clinical benefit of CRT in LBBB patients. ${ }^{5}$ Based on this evidence, current class I recommendations were restricted to patients with complete LBBB. The relationship between QRS duration and morphology requires further research. 
Table 1. Summary of Randomized Clinical Trials ${ }^{6}$ (With permission of Oxford University Press (UK) (c) European Society of Cardiology, www.escardio.org) Evaluating CRT in HF patients and Sinus Rhythm

\begin{tabular}{|c|c|c|c|c|c|c|c|c|}
\hline Trial & $\begin{array}{c}\text { No. } \\
\text { Patients }\end{array}$ & Design & $\begin{array}{c}\text { NYHA } \\
\text { Functional } \\
\text { Class } \\
\end{array}$ & LVEF & QRS & $\begin{array}{l}\text { Primary End- } \\
\text { points }\end{array}$ & $\begin{array}{l}\text { Secondary End- } \\
\text { points }\end{array}$ & Main Findings \\
\hline MUSTIC-SR & 58 & $\begin{array}{l}\text { Single-blinded, } \\
\text { crossover, } \\
\text { randomized } \\
\text { CRT vs OMT, } \\
6 \text { months }\end{array}$ & III & $<35 \%$ & $\begin{array}{l}\geq 150 \\
\mathrm{~ms}\end{array}$ & 6MWD & $\begin{array}{c}\text { NYHA class, } \\
\text { QoL, } \\
\text { peak VO2LV } \\
\text { volumes, } \\
\text { MR hospitaliza- } \\
\text { tions, } \\
\text { mortality }\end{array}$ & $\begin{array}{c}\text { CRT-P improved } \\
\text { 6MWD, } \\
\text { NYHA class, } \\
\text { QoL, peak VO2, } \\
\text { reduced LV vol- } \\
\text { umes and MR } \\
\text { and reduced } \\
\text { hospitalizations }\end{array}$ \\
\hline PATH-CHF & 41 & $\begin{array}{l}\text { Single-blinded, } \\
\text { crossover, } \\
\text { randomized RV } \\
\text { vs } \mathrm{LV} \text { vs BiV, } 12 \\
\text { months }\end{array}$ & III-IV & NA & $\begin{array}{c}\geq 150 \\
\mathrm{~ms}\end{array}$ & $\begin{array}{l}\text { Peak VO2, } \\
\text { 6MWD }\end{array}$ & $\begin{array}{l}\text { NYHA class, QoL } \\
\text { hospitalizations }\end{array}$ & $\begin{array}{l}\text { CRT-P improved } \\
\text { NYHA class, } \\
\text { QoL and 6MWD } \\
\text { and reduced } \\
\text { hospitalizations }\end{array}$ \\
\hline MIRACLE & 453 & $\begin{array}{l}\text { Double-blinded, } \\
\text { randomized } \\
\text { CRT vs. } \\
\text { OMT, } 6 \text { months }\end{array}$ & III-IV & $\leq 35 \%$ & $\begin{array}{l}\geq 130 \\
\mathrm{~ms}\end{array}$ & $\begin{array}{l}\text { NYHA class, } \\
\text { 6MWD , QoL }\end{array}$ & $\begin{array}{c}\text { Peak VO2 } \\
\text { LVEDD, } \\
\text { LVEF, MR } \\
\text { clinical composite } \\
\text { response }\end{array}$ & $\begin{array}{l}\text { CRT-P improved } \\
\text { NYHA class, } \\
\text { QoL and 6MWD } \\
\text { and reduced } \\
\text { LVEDD, MR and } \\
\text { increased LVEF }\end{array}$ \\
\hline MIRACLE-ICD & 369 & $\begin{array}{c}\text { Double-blinded, } \\
\text { randomized } \\
\text { CRT-D vs. } \\
\text { ICD, } \\
6 \text { months } \\
\end{array}$ & III-IV & $\leq 35 \%$ & $\begin{array}{c}\geq 130 \\
\mathrm{~ms}\end{array}$ & $\begin{array}{l}\text { NYHA class, } \\
\text { 6MWD, QoL }\end{array}$ & $\begin{array}{c}\text { Peak VO2 } \\
\text { LVEDD, LVEF, } \\
\text { MR } \\
\text { clinical composite } \\
\text { response } \\
\end{array}$ & $\begin{array}{l}\text { CRT-D improved } \\
\text { NYHA class, } \\
\text { QoL, peak VO2 }\end{array}$ \\
\hline CONTAK-CD & 490 & $\begin{array}{c}\text { Double-blinded } \\
\text { randomized } \\
\text { CRT-D vs. } \\
\text { ICD, } \\
6 \text { months }\end{array}$ & II-IV & $\leq 35 \%$ & $\begin{array}{l}\geq 120 \\
\mathrm{~ms}\end{array}$ & $\begin{array}{l}\text { NYHA class, } \\
\text { 6MWD, QoL }\end{array}$ & $\begin{array}{c}\text { LV volume, LVEF } \\
\text { composite of } \\
\text { mortality, VT/VF, } \\
\text { hospitalizations }\end{array}$ & $\begin{array}{l}\text { CRT-D improved } \\
\text { 6MWD, } \\
\text { NYHA class, } \\
\text { QoL, } \\
\text { reduced LV vol- } \\
\text { ume and } \\
\text { increased LVEF }\end{array}$ \\
\hline $\begin{array}{l}\text { MIRACLE- } \\
\text { ICD II }\end{array}$ & 186 & $\begin{array}{l}\text { Double-blinded, } \\
\text { randomized } \\
\text { CRT-D vs. } \\
\text { ICD, } \\
6 \text { months }\end{array}$ & II & $\leq 35 \%$ & $\begin{array}{c}\geq 130 \\
\mathrm{~ms}\end{array}$ & Peak VO2 & $\begin{array}{c}\text { VE/VCO2, } \\
\text { NYHA, } \\
\text { QoL, 6MWD, } \\
\text { LV } \\
\text { volumes and EF, } \\
\text { composite clinical } \\
\text { endpoint }\end{array}$ & $\begin{array}{l}\text { CRT-D improved } \\
\text { NYHA, } \\
\text { VE/CO2 and } \\
\text { reduced } \\
\text { LV volumes and } \\
\text { improved LVEF }\end{array}$ \\
\hline COMPANION & 1520 & $\begin{array}{l}\text { Double-blinded } \\
\text { randomized } \\
\text { OMT vs. } \\
\text { CRT-P / or } \\
\text { vs. CRT-D, } \\
15 \text { months }\end{array}$ & III-IV & $\leq 35 \%$ & $\begin{array}{c}\geq 120 \\
\mathrm{~ms}\end{array}$ & $\begin{array}{c}\text { All-cause } \\
\text { mortality or } \\
\text { hospitalization }\end{array}$ & $\begin{array}{l}\text { All-cause mortal- } \\
\text { ity, } \\
\text { cardiac mortality }\end{array}$ & $\begin{array}{c}\text { CRT-P and } \\
\text { CRT-D reduced } \\
\text { all-cause mortal- } \\
\text { ity or } \\
\text { hospitalization }\end{array}$ \\
\hline
\end{tabular}


Jurnal Kardiologi Indonesia

\begin{tabular}{|c|c|c|c|c|c|c|c|c|}
\hline CARE-HF & 813 & \begin{tabular}{|c|} 
Double-blinded \\
randomized \\
OMT vs. \\
CRT-P \\
29.4 months
\end{tabular} & III-IV & $\leq 35 \%$ & $\begin{array}{c}\geq 120 \\
\mathrm{~ms}\end{array}$ & $\begin{array}{c}\text { All-cause } \\
\text { mortality or } \\
\text { hospitalization }\end{array}$ & $\begin{array}{l}\text { All-cause mortal- } \\
\text { ity, } \\
\text { NYHA class, QoL }\end{array}$ & $\begin{array}{l}\text { CRT-P reduced } \\
\text { all-cause } \\
\text { mortality and } \\
\text { hospitalization } \\
\text { and improved } \\
\text { NYHA class and } \\
\text { QoL }\end{array}$ \\
\hline REVERSE & 610 & $\begin{array}{c}\text { Double-blinded, } \\
\text { randomized } \\
\text { CRT-ON vs. } \\
\text { CRT-OFF, } \\
12 \text { months }\end{array}$ & I-II & $\leq 40 \%$ & $\begin{array}{c}\geq 120 \\
\mathrm{~ms}\end{array}$ & $\begin{array}{c}\% \text { worsened } \\
\text { by clinical } \\
\text { composite } \\
\text { endpoint }\end{array}$ & $\begin{array}{c}\text { LVESV index, } \\
\text { heart failure } \\
\text { hospitalizations } \\
\text { and } \\
\text { all-cause mortality }\end{array}$ & $\begin{array}{l}\text { CRT-P/CRT-D } \\
\text { did not change } \\
\text { the primary end- } \\
\text { point and did } \\
\text { not reduce all- } \\
\text { cause mortality } \\
\text { but reduced } \\
\text { LVESV index and } \\
\text { heart failure hos- } \\
\text { pitalizations }\end{array}$ \\
\hline MADIT-CRT & 1820 & $\begin{array}{l}\text { Single-blinded, } \\
\text { randomized } \\
\text { CRT-D vs. } \\
\text { ICD, } \\
12 \text { months }\end{array}$ & I-II & $\leq 30 \%$ & $\begin{array}{c}\geq 130 \\
\mathrm{~ms}\end{array}$ & $\begin{array}{c}\text { All-cause } \\
\text { mortality or } \\
\text { heart failure } \\
\text { hospitalizations }\end{array}$ & $\begin{array}{c}\text { All-cause mortal- } \\
\text { ity } \\
\text { and LVESV }\end{array}$ & $\begin{array}{l}\text { CRT-D reduced } \\
\text { the endpoint } \\
\text { heart failure hos- } \\
\text { pitalizations or } \\
\text { all-cause mortality } \\
\text { and LVESV. } \\
\text { CRT-D did not } \\
\text { reduced } \\
\text { all-cause mortality }\end{array}$ \\
\hline RAFT & 1798 & $\begin{array}{l}\text { Double-blinded, } \\
\text { randomized } \\
\text { CRT-D } \\
\text { vs. ICD } \\
40 \text { months }\end{array}$ & I-II & $\leq 30 \%$ & $\begin{array}{c}\geq 120 \\
\mathrm{~ms}\end{array}$ & $\begin{array}{c}\text { All-cause } \\
\text { mortality or } \\
\text { heart failure } \\
\text { hospitalizations }\end{array}$ & $\begin{array}{l}\text { All-cause mortal- } \\
\text { ity } \\
\text { and cardiovascular } \\
\text { death }\end{array}$ & $\begin{array}{l}\text { CRT-D reduced } \\
\text { the endpoint } \\
\text { all-cause mortality } \\
\text { or heart } \\
\text { failure hospitaliza- } \\
\text { tions. In } \\
\text { NYHA III, } \\
\text { CRT-D only } \\
\text { reduced signif- } \\
\text { cantly all-cause } \\
\text { mortality }\end{array}$ \\
\hline
\end{tabular}

CARE-HF (Cardiac Resynchronization-Heart Failure); CONTAK-CD (CONTAK-Cardiac Defibrillator); COMPANION (Comparison of Medical Therapy, Pacing and

Defibrillation in Heart Failure); CRT-D (Cardiac Resynchronization therapy with Defibrillator); CRT-P (Cardiac Resynchronization Therapy Pacemaker); LV (Left Ventricular; LVEDD (Left Ventricular End-Diastolic Dimension); LVEF (Left Ventricular Ejection Fraction); LVESV (Left Ventricular End-Systolic Volume); MADIT-CRT (Multicenter Automatic Defibrillator Implantation Trial with Cardiac Resynchronization Therapy); MIRACLE (Multicenter InSync Randomized Clinical Evaluation); MIRACLE-ICD (Multicenter InSync Implantable Cardioverter Defibrillator trial); MR (Mitral Regurgitation); MUSTIC (Multisite Stimulation in Cardiomyopathies); No (Number of Patients); NYHA (New York Heart Association); PATH-CHF (Pacing Therapies in Congestive Heart Failure Trial); QoL( Quality of Life Score); RAFT (Resynchronization Defibrillation for Ambulatory Heart Failure Trial); VE/VCO2 (Minute Ventilation/ Minute Volume Carbondioxide Production); VF (Ventricular Fibrillation); VO2 (Volume of Oxygen); VT (Ventricular Tachycardia; 6MWD (6-min Walk Distance) 
In HF patients with NYHA functional class I-II, sinus rhythm, LVEF $\leq 30-40 \%$ and QRS duration $\geq 120-130 \mathrm{~ms}$, four RCTs which were MADIT-CRT, RAFT, REVERSE, and Multicenter InSync Implantable Cardioverter Defibrillator (MIRACLE-ICD) trials have demonstrated that CRT improves LV function, all-cause mortality and HF hospitalizations. ${ }^{6,12-15}$ However, improvement in functional status or quality of life among patients randomized to CRT were not too significant. Most patients enrolled had NYHA functional class II; only $15 \%$ in Resynchronization Reverses Remodelling in Systolic Left Ventricular Dysfunction (REVERSE) and $18 \%$ in Multicenter Automatic Defibrillator Implantation Trial with Cardiac Resynchronization Therapy (MADIT-CRT) were in NYHA functional class I. CRT did not reduce all-cause mortality of HF events among NYHA functional class I patients. Therefore, the recommendation is restricted to patients in NYHA functional class II.

Finally, there is no evidence of benefit in patients with $\mathrm{HF}$ and QRS < $120 \mathrm{~ms}$. In the Cardiac Resynchronization Therapy In Patients with Heart Failure and Narrow QRS (RethinQ) trial, CRT did not improve peak oxygen consumption (primary endpoint) or QoL in the subgroup of patients with QRS $<120$ $\mathrm{ms}$ and evidence of echocardiography dysscynhrony. ${ }^{6,16}$
Table 2. Indications for CRT in HF Patients and Sinus Rhythm ${ }^{6}$ (With permission of Oxford University Press (UK) (c) European Society of Cardiology, www.escardio.org)

\begin{tabular}{|c|c|c|}
\hline Recommendations & Class $^{\mathrm{a}}$ & Level $^{\mathbf{b}}$ \\
\hline $\begin{array}{l}\text { 1) LBBB with QRS } \\
\text { duration }>\mathbf{1 5 0} \text { ms. } \\
\text { CRT is recommended in } \\
\text { chronic HF patients and } \\
\text { LVEF } \\
\leq 35 \% \text { who remain in } \\
\text { NYHA } \\
\text { functional class II, III and } \\
\text { ambulatory IV despite } \\
\text { adequate } \\
\text { medical treatment. }\end{array}$ & I & A \\
\hline $\begin{array}{l}\text { 2) LBBB with QRS } \\
\text { duration } \mathbf{1 2 0 - 1 5 0 ~} \mathbf{~ m s .} \\
\text { CRT is recommended in } \\
\text { chronic HF patients and } \\
\text { LVEF } \\
\leq 35 \% \text { who remain in } \\
\text { NYHA } \\
\text { functional class II, III and } \\
\text { ambulatory IV despite } \\
\text { adequate } \\
\text { medical treatment. }{ }^{\text {d }}\end{array}$ & I & B \\
\hline
\end{tabular}

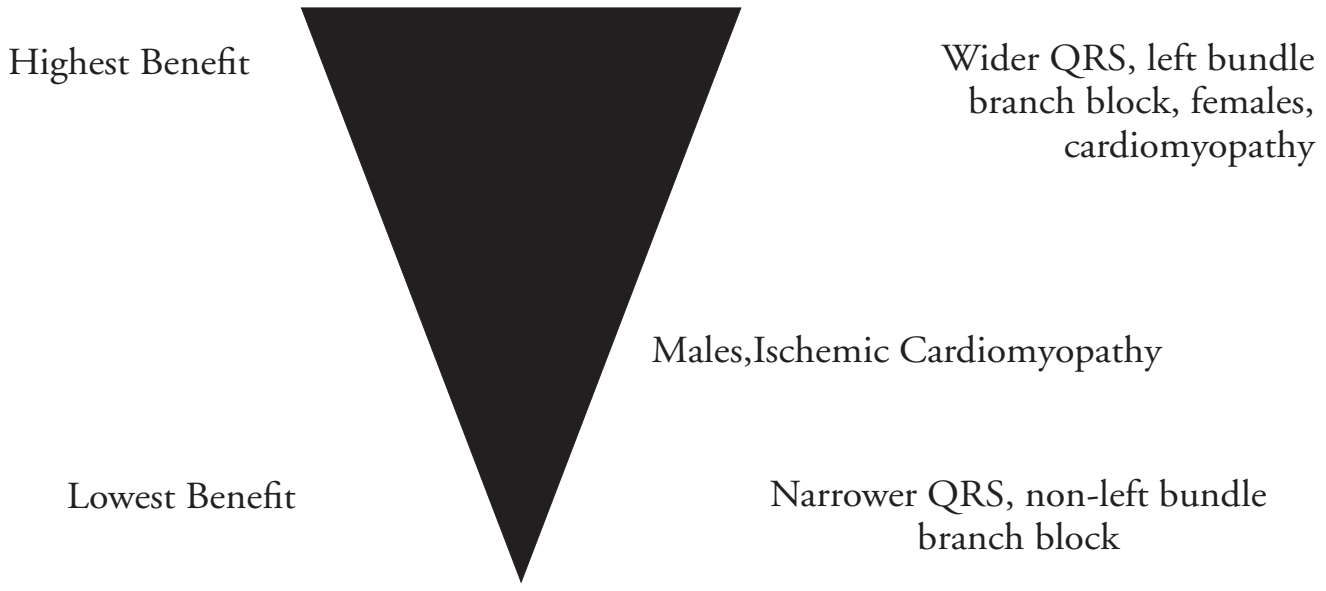

Figure 3. Benefit Scale of CRT Based on Clinical Factors6 (With permission of Oxford University Press (UK) (c) European Society of Cardiology, www.escardio.org) 


\begin{tabular}{|l|l|l|}
\hline 3) Non-LBBB with QRS & IIa & B \\
duration $>\mathbf{1 5 0}$ ms. & & \\
CRT should be considered & & \\
in & & \\
chronic HF patients and & & \\
LVEF & & \\
$\leq 35 \%$ who remain in & & \\
NYHA & & \\
functional class II, III and & & \\
ambulatory IV despite & & \\
adequate & \\
medical treatment. & \\
\hline 4) Non-LBBB with QRS & IIb & \\
duration $\mathbf{1 2 0}-\mathbf{1 5 0}$ ms. & & \\
CRT may be considered in & & \\
chronic HF patients and & & \\
LVEF & & \\
$\leq 35 \%$ who remain in & & \\
NYHA & & \\
functional class II, III and & & \\
ambulatory IV despite & & \\
adequate & & \\
medical treatment. & & \\
\hline 5) CRT in patients with & III & \\
chronic HF with QRS & & \\
duration & \\
$<120$ ms is not recom- & \\
mended & & \\
\hline
\end{tabular}

CRT (Cardiac Resynchronization Therapy); HF (Heart Failure); LBBB (Left Bundle Branch Block); LV (Left Ventricular); LVEF (Left Ventricular Ejection Fraction); NYHA (New York Heart Association)

${ }^{\mathrm{a} C l a s s}$ of recommendation.

bLevel of evidence.

'Reference(s) supporting recommendation(s).

dPatients should generally not be implanted during admission for acute decompensated HF. In such patients, guideline-indicated medical treatment should be optimized and the patient reviewed as an out-patient after stabilization. It is recognized that this may not always be possible.

Other randomized and double-blind study named Evaluation of Resynchronization Therapy for Heart Failure in Patients with a QRS Duration Lower Than $120 \mathrm{~ms}$ (LESSER-EARTH) was prematurely stopped due to safety concerns. ${ }^{6,17}$

\section{CRT In Heart Failure Management With Atrial Fibrillation (AF)}

There are two ways of considering CRT for AF patients, first, AF patients with moderate to severe HF with a hemodynamic indication for CRT. Second, patients with a fast ventricular rate with $\mathrm{HF}$ or LV dysfunction justifying a strong rate control strategy with an AV junction ablation. ${ }^{6}$

In the first way of considering CRT for AF patients were described in Multisite Stimulation in Cardiomyopathies (MUSTIC) AF trial.6,18 There was a slight but significant improvement in functional status in patients with NYHA functional class III, low LVEF, AF rhythm, and QRS $\geq 120$ ms at 6-month and 1-year follow-up. In the Ablate and Pace in AF (APAF) trial, in the patients with low LVEF, NYHA functional class $\geq$ III, AF rhythm, and QRS $\geq 120 \mathrm{~ms}$, CRT significantly reduced the primary endpoint, including death, hospitalizations or worsening of HF, as well as beneficial effect on LV reverse remodeling. ${ }^{6}, 19$

Second way, combination of AV junction ablation and CRT in uncontrolled heart rate of AF patients provided highly efficient rate control, regularization of the ventricular response, and also improved symptoms. ${ }^{6}$ Hence, CRT may prevent the potential LV asynchrony. The multi-center, randomized, and prospective APAF trial with 186 patients studied about CRT implantation followed by AV junction ablation. ${ }^{6,19}$ During a median followup of 20 months, CRT significantly decreased the primary composite endpoint (of death due to HF, hospitalization or worsening due to HF) by $63 \%$ in the overall population. The effects and efficacy of CRT were significantly consistent in patients who had $\mathrm{EF} \leq 35 \%$, NYHA functional class $\geq$ III, and QRS width $\geq 120 \mathrm{~ms}$, thus meeting the requirement of the guidelines.

\section{Conclusion}

The prevalence of HF is still high. This disease carries substantial risk of morbidity and mortality. Over 2.4 million patients are hospitalized and nearly 300,000 deaths annually are directly attributable to HF. HF is characterized by the inability of the heart to pump an adequate amount of blood to achieve the demand of the different organ systems and/or doing so at increased filling pressures. The most common abnormality 
Table 3. Indications for CRT in HF Patients and Atrial Fibrillation ${ }^{6}$ (With permission of Oxford University Press (UK) (c) European Society of Cardiology, www.escardio.org)

\begin{tabular}{|c|c|c|}
\hline Recommendations & Class $^{a}$ & Level $^{\mathrm{b}}$ \\
\hline $\begin{array}{l}\text { 1) Patients with HF, wide } \\
\text { QRS and reduced LVEF: } \\
\text { 1A) CRT should be } \\
\text { considered in chronic HF } \\
\text { patients, intrinsic QRS } \geq 120 \\
\text { ms and LVEF } \leq 35 \% \text { who } \\
\text { remain in NYHA functional } \\
\text { class III and ambulatory IV } \\
\text { despite adequate medical } \\
\text { treatment }{ }^{d} \text {, provided that a } \\
\text { BiV pacing as close to } 100 \% \\
\text { as possible can be achieved. }\end{array}$ & IIa & B \\
\hline $\begin{array}{l}\text { 1B) AV junction ablation } \\
\text { should be added in case of } \\
\text { incomplete BiV pacing. }\end{array}$ & IIa & B \\
\hline $\begin{array}{l}\text { 2) Patients with } \\
\text { uncontrolled heart rate } \\
\text { who are candidates for } \\
\text { AV junction ablation. } \\
\text { CRT should be considered in } \\
\text { patients with reduced LVEF } \\
\text { who are candidates for AV } \\
\text { junction ablation for rate } \\
\text { control. }\end{array}$ & IIa & B \\
\hline
\end{tabular}

AV (Atrioventricular); CRT (Cardiac Resynchronization Therapy); HF (Heart Failure); ICD (Implantable Cardioverter Defibrillator); LVEF (Left Ventricular Ejection Fraction); NYHA (New York Heart Association)

${ }^{a}$ Class of recommendation.

${ }^{b}$ Level of evidence.

'Reference(s) supporting recommendation(s).

dPatients should generally not be implanted during admission for acute decompensated HF. In such patients, guideline-indicated medical treatment should be optimized and the patient reviewed as an out-patient after stabilization. It is recognized that this may not always be possible.

conduction in HF patient is left bundle branch block (LBBB). Because of this block, the right ventricle made an earlier contraction than the left ventricle, instead of simultaneously. The result is an asynchronous contraction of the ventricles. Eventually, cardiac pump will lose its efficiency.. Almost $40 \%$ of HF patients have an asynchronous ventricular contraction caused by electrical delay, most often LBBB. CRT, a specialized and unique pacemaker, plays an important new role as a novel treatment in HF patients, despite many recent advances in medication. HF patients with proper and right indications like wide QRS complexes, low left ventricular ejection fraction (LVEF), LBBB, SR with conduction delay, and permanent AF have shown improvement of symptoms and QoL. Thus, CRT have been proven to reduce morbidity and mortality in HF patients.

\section{References}

1. Nasif, M, Alahmad A. Congestive heart failure and public health. Bioepidemiology (article online). (Cited 2015 May 22). Available from http://www.cwru.edu/med/epidbio/mphp439/ CongHeartFail.pdf

2. Shea JB, Sweeney MO. Cardiac resynchronization therapy: a patient's guide. Circulation. 2003;108:e64-6.

3. Bui AL, Horwich TB, Fonarow GC. Epidemiology and risk profile of heart failure. Nat Rev Cardiol. 2011; 8(1):30-41.

4. Washington Heart Rhythms Associates. CRT Figures 1 and 2 (cited 2015 May 22). Available from http://www.washingtonhra. $\mathrm{com} /$ pacemakers-icds/cardiac-resynchronization-therapy-crt. php

5. Budzikowski AS, Gabriels JK. Cardiac resynchronization technique. Medscape (article online). 2014. (Cited 2015 May 22). Available from http://emedicine.medscape.com/ article/1839506-technique

6. Brignole M, Auricchio A, Baron-Esquivias G, Bordachar P, et al. 2013 ESC guidelines on cardiac pacing and cardiac resynchroniztion therapy. Eur Heart J. 2013;34:2281-2329.

7. Cleland JG, Daubert JC, Erdmann E, Freemantle N, Gras D, Kappenberger L, Tavazzi L. The effect of cardiac resynchronization on morbidity and mortality in heart failure. N Engl J Med. 2005; 352:1539-49.

8. Bristow MR, Saxon LA, Boehmer J, Krueger S, Kass DA, De Marco T, Carson P, DiCarlo L, DeMets D, White BG, DeVries DW, Feldman AM. Cardiac-resynchronization therapy with or without an implantable defibrillator in advanced chronic heart failure. N Engl J Med. 2004; 350:2140-50.

9. Cazeau S, Leclercq C, Lavergne T, Walker S, Farma C, Linde C, Garrigue S, Kappenberger L, Haywood GA, Santini M, Baileul C, Daubert JC. Effects of multisite biventricular pacing in patients with heart failure and intraventricular conduction delay. N Engl J Med. 2001; 344:873-80.

10. Auricchio A, Stellbrink C, Butter C, Sack S, Vogt J, Misier AR, Bocker D, Block M, Kirkels JH, Kramer A, Huvelle E. Clinical efficacy of cardiac resynchronization therapy using left ventricular pacing in heart failure patients stratified by severity of ventricular of conduction delay. J Am Coll Cardiol 2003; 42:2109-16.

11. Abraham WT, Fisher WG, Smith AL, Delurgio DB, Leon AR, Loh E, Kocovic DC, Packer M, Clavell AL, Hayes DL, Ellestad 
M, Trupp RJ, Underwood J, Pickering F, Truex C, McAtee P, Messenger J. Cardiac resynchronization in chronic heart failure. N Engl J Med. 2002; 346:1845-53.

12. Moss AJ, Hall Wj, Cannom DS, Klein H, Brown MW, Daubert JP, Estes NA $3^{\text {rd }}$, Foster E, Greenberg H, Higgins SL, Pfeffer MA, Solomon SD, Wilber D, Zareba W. Cardiac-resynchronization therapy for the prevention of heart failure events. N Engl J Med. 2009; 361:1329-38.

13. Tang AS, Wells GA, Talajic M, Arnold MO, Sheldon R, Connolly S, Hohnloser SH, Nichol G, Birnie DH, Sapp JL, Yee R, Healey JS, Rouleau JL. Cardiac-resynchronization therapy for mild-to-moderate heart failure. N Engl J Med. 2010; 363:238595.

14. Linde C, Abraham WT, Gold MR, ST John Sutton M, Ghio $S$, Daubert C. Randomized trial of cardiac resynchronization in mildly symptomatic heart failure patients and in asymptomatic patients with left ventricular dysfuntion and previous heart failure symptoms. J Am Coll Cardiol. 2008; 52:1834-43.

15. Abraham WT, Young JB, Leon AR, Adler S, Bank AJ, Hall SA, Lieberman R, Liem LB, O'Connell JB, Schroeder JS, Wheelan KR. Effects of cardiac resynchronization on disease progression in patients with left ventricular systolic dysfunction, an indication for an implantable cardioverter-defibrillator, and mildly symptomatic chronic heart failure. Circulation. 2004;
110:2864-8.

16. Beshai JF, Grimm RA, Nagueh SF, Baker JH $2^{\text {nd }}$, Beau SL, Greenberg SM, Pires LA, Tchou PJ. Cardiac-resynchronization therapy in heart failure with narrow QRS complexes. N Engl J Med. 2007: 357:2461-71.

17. Thibault B, Harel F, Ducharme A, White M, Ellenbogen KA, Frasure-Smith N, Roy D, Philippon F, Dorian P, Talajic M, Dubuc M, Guerra PG, Made L, Rivard L, Andrade J, Khairy P, LESSER-EARTH Investigators. Cardiac resynchronization therapy in patients with heart failure and a QRS complex < 120 milliseconds: The evaluation of resynchronization therapy for heart failure (LESSER-EARTH) trial. Circulation. 2013; 127:873-81.

18. Linde C, Ledercq C, Rex S, Garrigue S, Lavergne T, Cazeau S, McKenna W, Fitzgerald M, Deharo JC, Alonso C, Walker S, Braunschweig F, Bailleul C, Daubert JC. Long-term benefits of biventricular pacing in congestive heart failure: results from the multisite stimulation in cardiomyopathy study (MUSTIC) study. J Am Coll Cardiol. 2002; 40:111-8.

19. Brignole M, Botto G, Mont L, Iacopino S, De Marchi G, Oddone D, Luzi M, Tolosana JM, Navazio A, Menozzi C. Cardiac resynchronization therapy in patients undergoing atrioventricular junction ablation for permanent atrial fibrillation: a randomized trial. Eur Heart J. 2011; 32:2420-9. 